\title{
IMPORTANCE AND USE OF SOCIAL MEDIA AMONG THE POST GRADUATE STUDENTS AND RESEARCH SCHOLARS OF ALAGAPPA UNIVERSITY, KARAIKUDI: A STUDY
}

\author{
A. Lavanya ${ }^{1}$, S. k. Abdul Gaffar ${ }^{2}$, Dr. S. Kishore Kumar ${ }^{3}$ \\ ${ }^{1}$ Research Scholar, Department of Library and Information Science, \\ Alagappa University, Tamil Nadu, \\ Email-lavanyamphil92@gmail.com \\ ${ }^{2}$ Research Scholar, Department of Library and Information Scie006Ece, \\ AlagappaUniversity, TamilNadu, \\ Email-gaffaram@gmail.com \\ Orcid id - 0000-0003-0500-8119 \\ ${ }^{3}$ Deputy Librarian, Department of Library and \\ Information Science, Alagappa University, Tamil Nadu, \\ Email-libkishore@yahoo.com \\ orcid id-0000-0001-7694-4807
}

\section{Manuscript Info}

\section{Manuscript History}

Received: 01 January 2021

Final Accepted: 22 February 2021

Published: 10 March 2021

Online Published: April 2021

DOI: http://dx.doi.org/10.35337/EIJLITR.2021.1401

(C) A. Lavanya , S. k. Abdul Gaffar, Dr. S. Kishore Kumar The Author. This is an open access article under the terms of the Creative Commons Attribution License 4.0, which allows use, distribution and reproduction in any medium, provided the original work is properly cited.

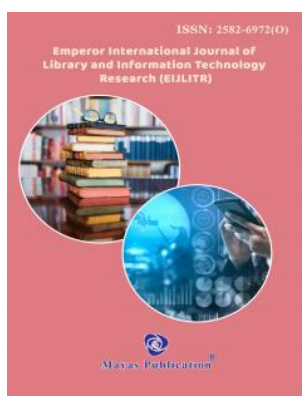

\section{Abstract}

An attributes of the evaluation is to find importance and use of online media among post graduated class understudies and assessment specialists of Alagappa University, Karaikudi. 120 outlines were appropriated to the post graduated class understudies and assessment scientists of Alagappa University, Karaikudi. Out of 120 reviews circled, 90 were gotten back with full focal core interests. $58.88 \%$ of the respondents have a spot with the female class, $33.88 \%$ of the respondents have a spot with the age get-together of 20-25, and $40 \%$ of the respondents have a spot with the $\mathrm{Ph}$. D. plan. Analysts, $41.11 \%$ respondents have a spot with the solicitation for Rural, $57.77 \%$ respondents have a spot with the using the High, $26.66 \%$ of the respondents using have a spot with What's application, maintained Mobile $42.22 \%$ for getting to online media, $28.88 \%$ of the respondents have a perceive the intermittent Google chrome, Library $40 \%$ for using electronic media, $44.44 \%$ of the respondents using the Social media Many time in a day, 33.33\% of the To separate eminent considerations, $44.44 \%$ respondents Highly satisfied. 
Keywords:: Social media, Use of online media, Accessing, Face book, New examinations, what's the application

\section{INTRODUCTION}

Online Media as a get-together of Internet-set up applications that development regarding the philosophical and mechanical foundations of Web 2.0, and that grant the creation and exchange of User Generated Content, finds the key imparting in any case. "Oxford English Dictionary depicted online media as "complaints and applications that engage customers to make and share substance or look into long show up at accommodating correspondence".. In direct terms, it might be known as a standard social instrument of correspondence. This new kind of media makes the trading of text, photos, sound, video, and information in ordinary steadily fluid among web customers. The Social Media cements Facebook, Twitter, regions, YouTube, Flickr, What's application, etc, which are seen as completely vast explicit contraptions.

In the earlier years, online media complaints have gotten normal; giving young people another way to deal with oversee unite as one with each other and talk with the world. Long show up at agreeable correspondence got acclaimed some spot in the degree of 2004 and 2006 after Facebook and MySpace were made. Facebook, for example has in excess of 500 million people and it is presently making and overall $85 \%$ of school understudies are Facebook customers (Schneider, 2009). These numbers are depended on to make since Facebook customers will continue to make. The way web customers accomplice and talk with each other has changed and continues to advance. These customers in the end associate through the web and it decreases the individual socialization that has been around forever. Long show up at social correspondence protests have influenced our social joint effort by changing the way where we interface close, how we get information, and the portions of our gatherings of individuals and affiliations.

The utilization of online media by library neighborhood little importance yet truly it is for the most part used to fulfill a variety of targets. It is potential gadgets to empower a ton closer relationship among libraries and their accomplices to pass on customer affiliations and resources. It is an amazing explicit contraptions to help labor force, staff and understudies anotherly.

\section{Social Media}

Electronic media is an online gadget for sharing and separating information among people. Online media is related with structures affiliation and frameworks relationship in a way that keeps up trust among social gatherings and affiliations included. Any site which licenses customers to permit their snippets of data, sees and supports correspondences and neighborhood can be allocated an electronic media. It is difficult to give an express significance of the term online media. Many are confused with the use of the term with others like agreeable correspondence, social news, web 2.0, wikis, etc We should chip away at the term by taking the words and uncovering them in their different ramifications.

Social: Social frameworks identifying with obliged or portrayed by the all around organized association or relations.

Media: Media prompts the correspondence like radios, TV, papers, magazines that contact people completely. So we can say that electronic media is a social instrument of correspondence. It will in general be known as a framework and a point of convergence for broadcasting correspondence. 


\section{REVIEW OF LITERATURE}

Boateng (2016) drove an assessment in four schools to investigate the impact of electronic media developments needing to vivify significant thinking cutoff points, backing, and data progress. Today online media has been seen by higher foundations, making it a phase where understudies team up with their educators, specific understudies and other higher experts paying little psyche to what you look like at it. This from this point forward required the evaluation to examine and take a gander at how online media has influenced on understudies' educational life. The appraisal begged an enthusiastic technique in assessing these impacts. Ten by and large understudies chose for take an interest in the evaluation. The experts got a consistent inspecting system in picking individuals. The model fuses 5 female and 5 male understudies with two understudies each keeping an eye out for different tasks including, Comparative Education, Higher Education, Public Policy, World Economics and Environmental Science. The data assembled was then Transcribed and arranged subject to the authentic reactions of individuals. Basic centers were then bleeding edge from the records. The data of this evaluation was bankrupt down inductively, starting with the unsavory data including various wellsprings of information and starting there extending a few unequivocal subjects. In like manner, watchwords were recorded on the edge and some time later accumulated into different subthemes and subjects.

Roebuck, et.al. (2013) isolated the impact additionally, it attempts to see the advantages and concerns work power have with the utilization of online media for study lobby heading. Two-Way Multivariate Analysis of Variance (MANOVA) technique was used to check whether separations existed between two ward factors and (a) sex, (b) clear insightful positions, and (C) sex *rank to pick whether there are any alliance impacts between sexual directions with respect to the importance of their impression of advantages and stresses over online media uses for study lobby course as they travel through the conditions After a review of the association, an outline was developed that investigates the usage of electronic media and PDAs and highlights the points of view and vibes of instructors about electronic media. Graph tends to included 15 Likert-type scale, a couple of part data questions, a couple of opencompleted sales. (See the Appendix for complete assessment questions.) The assessment was reviewed by an expert for contemplations before it was passed on. Following this, Institutional Review Board support was searched for. At whatever point ensuring was gained, the assessment was appropriated electronic using Qualtrics, an online evaluation researching programming undertaking to the experts' own grounds likewise as to two LinkedIn Groups named "Critical level planning Teaching and Learning" (28,081 people) and "The Teaching Professor" (25,550 people).

Kaur, et.al investigated an evaluation on a monstrous association made in a customer and library resources. Online media is such a significant resource that it can spread a piece of information to various customers in a more secure and strong way, in this way electronic media can be used for advancement of library affiliations. The current appraisal is an undertaking to understand the current status care, data and disposition of clinical controllers about online media and its usage in transport of library affiliations. The regulator used the examination framework for get-together of data for the current evaluation. A selfformed investigation was proposed for motivation to accumulate data about the establishment available at the clinical school libraries for access of electronic media application and the respondents for the comparative were chiefs/in-charges of the school libraries under examination. The appraisal period was from January to April 2018. The conceded aftereffects of the assessment uncovered that $75 \%$ of the watchmen consider various organizations of electronic media to be used for giving library affiliations. $87.5 \%$ of the respondents for instance heads yielded that they are or will use online media applications for correspondence with customers, followed by reference relationship with $75 \%$ responses. A greater piece of the respondents from the libraries of clinical schools are not substance with the current establishment open for approval to electronic media with $75 \%$ responses. About piece of the regulators showed uncovered structure as one of the immense purposes behind disillusionment, followed by the lack of planning/limits with $37.5 \%$ responses. 
Baruah (2012) explains how electronic media like Facebook, Twitter, orkut, MySpace, Skype, etc, are used all things considered with a conclusive objective of correspondence. Possibly the standard advantages of the usage of online media is the electronic sharing of data and information among different get-togethers of people. Online media can basically change the character of our public exercises, both on a social and a region. The assessment is from a general viewpoint an enthusiastic and quantitative evaluation of the work and significance of online media as an instrument of sensible correspondence. To unequivocally dismantle the abundancy of online media, the assessment technique was used for examination, as this was found to be the most appropriate strategy to do an outline to find the making importance and the utilization of electronic media as an instrument of correspondence. Information framework was equivalently used for the current evaluation. The zone that has been decided for the current assessment is Guwahati city which is savvy changing into a general area in the north-eastern piece of India. A model evaluation was done among the occupants of Guwahati city. A proportion of carelessly picked 200 sampless people living in the metropolitan zones of Guwahati city has been contemplated. Wellsprings of data: Data have been accumulated from both key and discretionary sources. Focal sources join study work done among the occupants of Guwahati city. Report appraisal of the partner sources merges the web, magazines, books and journals has been done to consider the impact and the use of electronic media in the social occasion environment and its potential for future unanticipated turn of events.

Akakandelwa, et.al. (2018) has encouraged an examination on satisfying and social surface. In that capacity, understudies are spending a liberal piece of their experience through online media. School understudies and youth are seen as the best customers of these levels of progress. Despite a making corpus of making on the use out of online media all through the planet, there is a shortage of assessment in Zambia on how electronic media affects understudies' public movement. This illustrative, exploratory appraisal analyzed such online media stages understudies typically use, the degree of time understudies spend through electronic media, the explanations behind which understudies use the online media and the impact of electronic media use on understudies' public action. Complete self-encouraged analyzes and their responses were poor down using the Statistical Package for the Social Sciences (SPSS) getting 23. Results showed that the most generally used electronic media stage was What's application, a monster piece of the endeavored understudies announced enough dazzling in this online media application between 31 to an hour constantly. The evaluation system was used to demand data and information from a depiction of understudies considering A Bachelor of Arts in Library and Information Science (BALIS) and a Bachelor of Special Education (BASE), School of Education, University of Zambia. A depiction of 240 individuals was advantageously picked during address hours of the second semester of the 2016/17 savvy year. An outline was engineered by the experts to gather data. The data got was poverty stricken down using the Statistical Package for the Social Science, Version 23.

\section{OBJECTIVES}

$>$ See the utilization of electronic media post Graduate Students and Research Scholars.

$>$ To separate the most had a great time for getting the chance to electronic media.

$>$ To know the appraisal of electronic media and the relationship of the library.

$>$ To see the help electronic media.

$>$ To find the repeat of utilization of online media

To pick how much online media area are significant in understudies and Research Scholar educational activities

\section{METHODOLOGY}

The outlines strategy for the blend of the data is store genuine for get-together data particularly from limitless respondents looking out for a specific gathering. The power examination other than recognized the review system and got comfort enthusiastic taking a gander at method for get-together data from Research Scholars and Post graduated class understudies of Alagappa University, Karaikudi. An inflexible number of 120 reviews were passed on and 90 fittingly recorded investigations were gotten back. Subsequently picked 90 audits are used for assessment of data. 


\section{DATA ANALYSIS AND DISCUSSION}

TABLE 1

GENDER WISE DISTRIBUTION OF RESPONDENTS (N=90)

\begin{tabular}{|l|l|c|c|}
\hline Socio- demography & Frequency & No. of Respondents & Percentage \\
\hline \multirow{4}{*}{ Gender } & Male & 37 & 41.11 \\
\cline { 2 - 4 } & Female & 53 & 58.88 \\
\hline \multirow{5}{*}{ Age group } & $20-25$ & 30 & 33.33 \\
\cline { 2 - 4 } & $26-30$ & 22 & 24.44 \\
\cline { 2 - 4 } & $31-35$ & 16 & 17.77 \\
\cline { 2 - 4 } & $36-40$ & 12 & 13.33 \\
\cline { 2 - 4 } & Above 41 & 10 & 11.11 \\
\hline \multirow{4}{*}{ Residing area } & Postgraduate & 26 & 28.90 \\
\cline { 2 - 4 } & M. Phil & 28 & 31.11 \\
\cline { 2 - 4 } & Ph. D & 36 & 41.11 \\
\cline { 2 - 4 } & Rural & 37 & 33.33 \\
\cline { 2 - 4 } & Urban & 30 & 25.55 \\
\cline { 2 - 4 } & Semi Urban & 23 & \\
\hline
\end{tabular}

Table 1 shows the sexual direction smart flow of respondents. The table shows that $58.88 \%$ of the respondents have a spot with the female strategy and $41.11 \%$ have a spot with the male solicitation. By a long shot a large portion of the respondents have a spot with the female class. While It is obvious from table to that among the overall 90 respondents $33.33 \%$ of the respondents host a spot with the age gathering of $20-25,24.44 \%$ of the respondents have a spot with $26-30,17.77 \%$ of the respondents have a spot $31-35,13.33 \%$ of the respondents has a detect a day and a half, $11.11 \%$ of the respondents have a spot with the age get-together of more than 41 . Among the $40 \%$ of the respondents have a spot with the Ph. D Scholar, $31.11 \%$ of the respondents have a spot with the M.Phil $28.90 \%$ of the respondents are PG understudies. While that $41.11 \%$ of the respondents has a spot with the depiction of normal areas, $33.33 \%$ of the respondents have a spot with the course of action of metropolitan spaces, relatively as $25.55 \%$ of the respondents have a spot with the social affair of Semi Urban.

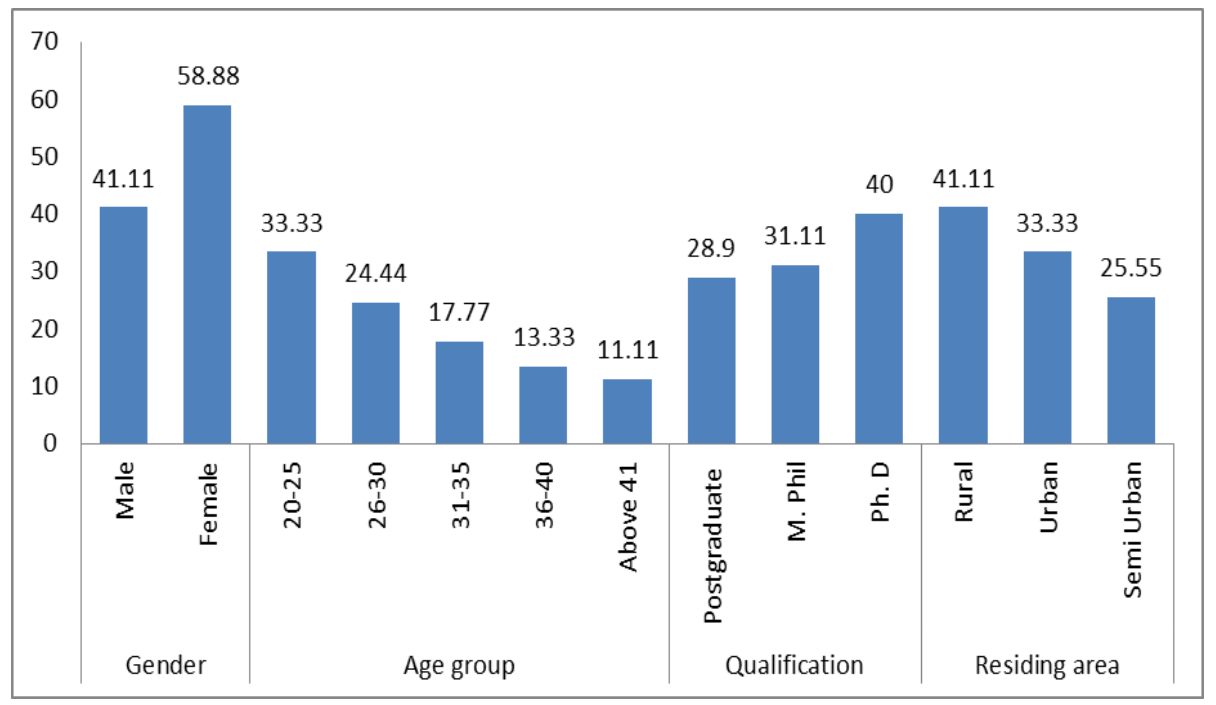

Figure 1: Gender wise distribution of respondents 
TABLE 2

USAGE LEVEL OF SOCIAL MEDIA AMONG THE RESPONDENTS

\begin{tabular}{|c|l|c|c|}
\hline S.No & Frequency & No. of Respondents & Percentage \\
\hline 1 & High & 52 & 57.77 \\
\hline 2 & Moderate & 28 & 31.11 \\
\hline 3 & Low & 10 & 11.11 \\
\hline Total & & 90 & 100 \\
\hline
\end{tabular}

Table 2 uncovers the repeat of use of online media assignment of respondents. In this assessment, 57.77\% respondents have a spot with the using the High, 31.11\% respondents using the use online media Moderate, $11.11 \%$ respondents have a spot with the Low.

TABLE 3

USAGE PATTERN OF SOCIAL MEDIA AMONG THE RESPONDENTS

\begin{tabular}{|l|l|c|c|}
\hline S.No & Browser & No. of Respondents & Percentage \\
\hline 1 & Face Book & 19 & 21.11 \\
\hline 2 & Twitter & 17 & 18.88 \\
\hline 3 & Wikipedia & 12 & 13.33 \\
\hline 4 & LinkedIn & 10 & 11.11 \\
\hline 5 & What's app & 24 & 26.66 \\
\hline 6 & Other & 8 & 8.88 \\
\hline Total & & 90 & 100 \\
\hline
\end{tabular}

Table 3 uncovers that $26.66 \%$ of the respondents using have a spot with What's application, $21.11 \%$ respondents have a spot with the use Face book, 18.88 \% respondents have a spot with the Twitter, $13.33 \%$ respondents have a spot with the Wikipedia, $11.11 \%$ respondents have a spot with the LinkedIn, $8.88 \%$ respondents usage of program for Others.

TABLE 4

SOCIAL MEDIA ACCESS- WISE DISTRIBUTION OF RESPONDENTS

\begin{tabular}{|c|l|c|c|}
\hline S.No & Accessing Social Media & No.of Respondents & Percentage \\
\hline 1 & Mobile & 38 & 42.22 \\
\hline 2 & Laptop & 32 & 35.55 \\
\hline 3 & PCs & 20 & 22.22 \\
\hline Total & & 90 & 100 \\
\hline
\end{tabular}

Table 4 highlights the supported strategies for getting to online media. The result shows that a significant level of the respondents supported Mobile $42.22 \%$ for having the opportunity to online media followed by the Laptop $35.55 \%$, PCs $22.22 \%$ getting to.

TABLE 5

USAGE PATTERN OF DIFFERENT BROWSE AMONG THE RESPONDENTS

\begin{tabular}{|c|l|c|c|}
\hline S.No & \multicolumn{1}{|c|}{ Browser } & No.of. Respondents & Percentage \\
\hline 1 & Google Chrome & 26 & 28.88 \\
\hline 2 & Internet Explore & 20 & 22.22 \\
\hline 3 & Opera & 18 & 20 \\
\hline 4 & Safari & 16 & 17.77 \\
\hline 5 & Fire Fox & 10 & 11.11 \\
\hline Total & & 90 & 100 \\
\hline
\end{tabular}


Table 5 shows that $28.88 \%$ of the respondents have a spot with the repeat Google chrome, $22.22 \%$ respondents to the use of Internet swashbuckler, $20 \%$ respondents have a spot with using Opera, $17.77 \%$ respondents to the use of Safari , $11.11 \%$ respondents have a spot with the using program for Fire Fox.

\section{TABLE 6}

LOCATION WISE USAGE OF SOCIAL MEDIA AMONG THE RESPONDENTS

\begin{tabular}{|c|l|c|c|}
\hline S.No & \multicolumn{1}{|c|}{ Places } & No.of. Respondents & Percentage \\
\hline 1 & Library & 36 & 40 \\
\hline 2 & Department & 27 & 30 \\
\hline 3 & Internet Browsing centre & 20 & 22.22 \\
\hline 4 & Home & 7 & 7.77 \\
\hline Total & Hostel & 90 & 100 \\
\hline
\end{tabular}

Table 6 highlights the supported spots using online media. The results shows that a significant degree of respondents supported the Library $40 \%$ for using online media followed by the Department $30 \%$, the Internet examining center $22.22 \%$, Home $7.77 \%$.

TABLE 7

USING FREQUENCY OF SOCIAL MEDIA AMONG THE OF RESPONDENTS

\begin{tabular}{|c|l|c|c|}
\hline S.No & Frequency of using & No. of. Respondents & Percentage \\
\hline 1 & Many time in a day & 40 & 44.44 \\
\hline 2 & Once in a day & 9 & 10 \\
\hline 3 & Twice in a day & 16 & 17.77 \\
\hline 4 & Always online & 25 & 27.77 \\
\hline Total & & 90 & 100 \\
\hline
\end{tabular}

Table 7 reveals that $44.44 \%$ of the respondents use online media much time a day, $27.77 \%$ reliably on the web, $17.77 \%$ multiple times each week, $10 \%$ once each day.

TABLE 8

\section{PURPOSE WISE USING OF SOCIAL MEDIA AMONG THE RESPONDENTS}

\begin{tabular}{|c|l|c|c|}
\hline S.No & \multicolumn{1}{|c|}{ Purpose } & No. of. Respondents & Percentage \\
\hline 1 & Friendly Communication & 26 & 28.88 \\
\hline 2 & Academic & 20 & 22.22 \\
\hline 3 & To publish writings & 14 & 15.55 \\
\hline 4 & To discuss New ideas & 30 & 33.33 \\
\hline Total & & 90 & 100 \\
\hline
\end{tabular}

Table 8 shows that a large portion of the respondents, $33.33 \%$ of the respondents, to discuss novel musings, $28.88 \%$ of the respondents Friendly Communication, $22.22 \%$ have a spot with the Academic, $15.55 \%$ have a spot with the T circulate works.

\section{TABLE 9}

SATISFACTION LEVEL WISE DISTRIBUTIONS OF THE RESPONDENTS

\begin{tabular}{|c|l|c|c|}
\hline S.No & Satisfaction & No. of. Respondents & Percentage \\
\hline 1 & Highly Satisfied & 40 & 44.44 \\
\hline 2 & Satisfied & 26 & 28.88 \\
\hline 3 & Neutral & 10 & 11.11 \\
\hline 4 & Dissatisfied & 9 & 10 \\
\hline 5 & Highly Dissatisfied & 5 & 5.55 \\
\hline Total & & 90 & 100 \\
\hline
\end{tabular}


Table 9 uncovers the Satisfaction Level-Wise Distributions of Respondents. In this examination $44.44 \%$ respondents significantly satisfied, $28.88 \%$ respondents Satisfied, $11.11 \%$ respondents Neutral, $10 \%$ respondents Dissatisfied, $5.55 \%$ respondents Highly Dissatisfied.

\section{CONCLUSION}

The understudies and examination scientists' importance and usage of Social Media among Post Graduate Students and Research Scholars of Alagappa University, Karaikudi: A Study. Utilization of online media among understudy and examination agents in update data, electronic learning and to team up with collaborators, subject arranged specialists and accomplices and other related academic activities. Electronic media instruments are a tremendous heap of basic in seeking after their educational activities Student teachers use online media to find consistent information. Online media is additionally seen as a convincing exertion instrument, helping regulators with progressing made by assistant significantly more basically with the more sweeping media neighborhood.

\section{ACKNOWLEDGEMENT}

This article has been formed with the financial assistance of RUSA - Phase 2.0 honor approved vide Letter No. F.24-51/2014-U, Policy (TNMulti-Gen), Dept. of Edn. Govt. of India, Dt.09.10.2018

\section{REFERENCES}

1. Nagaraja, S., Shashikiran, M., Mahadeva, S., and Mousumee, M. (2016). Care and Use of Social Media by Student Teachers: A Study. Int J Next Gener Libr Technol, 4, 1-14.

2. Owusu-Acheaw, M., and Larson, A. G. (2015). Use of online media and its impact on academic execution of tertiary foundation understudies: An appraisal of understudies of Koforidua Polytechnic, Ghana. Journal of Education and Practice, 6(6), 94-101.

3. Paquette, H. (2013). Online media as a propelling contraption: A making review.

4. Boateng, R., and Amankwaa, A. (2016). The impact of online media on understudy educational life in critical level planning. All around Journal of Human-Social Science, 16(4), 1-8.

5. Roebuck, D., Siha, S., and Bell, R. L. (2013). Labor force use of online media and phones: Analysis of advantages and concerns. Interdisciplinary Journal of E-Learning and Learning Objects, 9, 171

6. Kaur, S., and Manhas, R. (2019). Care, data, atmosphere and utilization of online media among supervisors and in libraries of clinical schools of Punjab: An evaluation. IP Indian Journal of Library Science and Information Technology, 3(2), 70-73.

7. Baruah, T. D. (2012). Sufficiency of Social Media as a mechanical party of correspondence and its potential for development engaged affiliations: A more unobtrusive than normal level evaluation. By and large Journal of Scientific and Research Publications, 2(5), 1-10.

8. Akakandelwa, A., and Walubita, G. (2018). Understudies' Social Media Use and its Perceived Impact on their Social Life: A Case Study of the University of Zambia.

9. Aggarwal, S. (Ed.). (2016). Online media in libraries. New Delhi, India: Ess Publications. 